THURSD $\Lambda$ Y, JULY 8, I 880

\section{THE TAY BRIDGE}

$\mathrm{T}^{\mathrm{H}}$ $\mathrm{E}$ Report of the Court of Inquiry appointed to investigate the circumstances of the fall of the Tay Bridge last December has now been made public. There appears to be some difference of opinion amongst the members of the court respecting the scope of the inquiry and the duties placed upon them by the Board of 'Trade, in consequence of which two separate reports appear together, one by Col. Yolland, Chief Government Inspector of Railways, and Mr. Barlow, President of the Institution of Civil Engineers, and the other by Mr. Rothery, the Wreck Commissioner. The former report describes in detail the design and method of crection adopted in the bridge, giving also a description of the various alterations in the plan which were rendered necessary as the work progressed.

The bridge was 3,465 yards in total length, divided into 86 spans, and it was the central portion, of 3,149 fect in length, which fell on the evening of December 28 . As originally designed, this central portion was to consist of lattice girders of 200 fect span, carried by brickwork piers somewhat over 80 feet in height from high-water level, but as the river bottom turned out to be different from what was expected from the borings, and the difficulty of oblaining a secure foundation greater, cleven spans of 245 feet and two of 227 feet were substituted, and braced iron piers were adopted in the place of brickwork, as imposing a less weight on the foundations. It is these piers which at the inquiry chiefly received attention, as there can be little doubt that they were the immediate cause of the catastrophe. The process of floating out and sinking the caissons for these piers has already been described in these columns, and so successfully was this-certainly the most difficult and hazardous part of the undertakingaccomplished, that no suggestion of insufficient strength has been made, and in the Report it is stated that therc is nothing to indicate any movement or settlement in the foundations of the piers which fell.

The caissons were lined with brickwork and filled with concrete, on which was built a hexagonal pier of masonry carricd up to 5 feet above high-water mark. Upon this picr was built up six cast-iron columns secured by holdingdown bolts to the masonry at the angles of the hexagon. The columns were made up of lengths united by flanges and bolts, and connected with each other by horizontal struts and diagonal ties. The up-stream and downstream columns were each 18 inches in diameter, the remaining four, 15 inches; all were inclined 12 inches inwards at the top. The piers thus formed were from $8 \mathrm{r}$ to 83 feet in height from the top of the masonry to the under-side of the girders. The diagonal bracing consisted of flat bars attached to the columns by means of "lugs", cast on them, being secured at onc cxtremity by a screwbolt passing through the lugs and bar, and at the other by a strap provided with a gib and cotter for tightening up. The horizontal struts consisted of two channel-bars bolted bark to back to a single lug on cach column.

It will thus be scen that all vertical load must be borne entirely by the columns, and with the exception of the Vor. $x x I 1,-N o .55^{8}$ small transverse resistance of the latter the whole of any lateral pressure must be transinitted by the bracing.

Whether as designed the bridge would have been strong enough for its work if the materials and workmanship had been good throughout is very doubtful, but, as carried out, the evidence shows distinctly that it was not sufficiently substantial for the heavy traffic and severe gales to which it was exposed. When everything was tight and in good order the bridge, at the time of its inspection by General Hutchinson in February, 1878, showed great rigidity under the tests imposed by him, but by October of the same year so much slackness had made its appearance in the bracing that, besides the ordinary keying-up by driving the cotters, more than 100 packing-pieces about three-eighths of an inch thick had to be introduced in different parts.

Respecting the immediate causc of the accident the Court states-" In our opinion the weight of evidence points out the cross bracing and its fastening by lugs as the first part to yield." This we believe the calculations of Dr. Pole and Mr. Stewart, taken in connection witis the experiments of Mr. Kir'aildy, are quite sufficient to establish. With a wind pressure of 30 lbs. to the square foot on the windward girder and train, and half this amount on the leeward girder, the stress on the tie-bar most severely strained, would be 16.8 tons, or 10.18 tons: per square inch; again, with a wind pressure of 40113 . to the square foot the stress on the tic-bar would be $22 \%$ tons. Now, as Mr. Kirkaldy's experiments, made by order of the court on some of the tie-bars remoried from the bridge, showed that they broke with a load of from I 9 to 23 tons, and the corresponding lugs with a load of 23 to 25 tons, it is pretty cortain that the ultimate strength of this part of the structure would be reached by a wind pressure of 40 lbs. to the square foot. And in addition to this more variation is to be expected in the strength of the lugs, as some at least were admitted to be of baci manufacture, and when the pier was most severely strained it would be some of the worst lugs in the lower tiers that would be the first to yield; thus the samples taken for testing would not be likely to embrace specimens of the lowest strength, as these would probably have already griven way.

Again, it does not appear necessary to assume a wind pressure of in lbs. per square foot to ensure the destruction of the pier; the stresses above mentioned are clue mercly to the statical pressure, and it can hardly be denied in the face of the evidence respecting the details of the structure that there would be a great deal of motion duc to backlash over and above the elastic yielding of the material. Thus a much lower pressure would produce the effects calculated for one of 40 lbs. per square foot.

The principal conclusions arrived at by the court are that there is no indication of settlement 'in the foundations, that the wrought iron employed was of fair strength, though not of high quality as regarcls toughness, that the cast iron was fairly good, that the main girders were of stifficient strength, and that the iron piers, though strong enough to sustain the vertical load, were insufficient to resist the lateral action of heavy gales from the weakness of the cross bracing and its fastenings; that the railway company did not enforce the recommendation of General Hutchinson by limiting the speed of trains over the 
bridge to twenty-five miles per hour, much higher speed being frequently run; that while of opinion that the fall of the bridge was occasioned by the yielding of the cross bracing and fastenings, it might possibly have been due to the fracture of one of the outward leeward columns.

Col. Yolland and Mr. Barlow conclude by stating "that there is no requirement issued by the Board of Trade respecting wind pressure, and there does not appear to be any understood rule in the engineering profession regarding wind pressure in railway structures; and we therefore recommend that the Board of Trade should take such steps as may be necessary for the cstablishment of rules for that purpose."

Mr. Rothery, in his independent report, while stating that there is an entire agrecment between himself and his colleagues in the conclusions arrived at from the evidence, goes further than them, and unhesitatingly apportions the blame among the different parties concerncd. On the recommendation that the Board of Trade should establish rules providing for wind pressure, he differs from his colleagues, emphatically stating that it is for the engineering profession to make them, and evidently regards the superficial character of an official inspection as no great evil.

Where French engineers have long adopted 270 kilogrammes per square metre, and many English engineers, on the authority of Rankine, the equivalent $55 \mathrm{lbs}$. per square foot, while nearly the same figure is used in America, it seems strange that so much difference of opinion should be found to exist; but one thing at least is certain, that the instruments at present in use for measuring wind pressure are exceedingly crude and liable to error, and that until these are improved and much increased in number there is little chance of being on the spot when these excessive pressures occur, or of truthfully recording them when met with.

Respecting the transfer of these responsibilities to a Government Department, we believe that such apronstring policy would be fatal to the profession of the civil engineer; we would rather see the Board of Trade Inspection, which at least is formal and superficial, relaxed than any attempt made to increase its efficiency. The medical profession does not require a fatherly department to watch over its operations or give an opinion on an amputation; why then should the engineering profession? It cannot be too clearly understood that an engineering work cannot be successfully carried out by mere rule of thumb or even by the copious use of "Molesworth" or "Rankine" ; each operation is to some extent a physical experiment subject to known laws, but under variable conditions. The physicist and the engineer have already to a great extent established the laws for him, but it remains for the scientific engineer to carefully watch their operation, and thus gain that practical experience which will enable him to deal with each special case as it arises.

The conclusions we draw from the evidence and report are that the design of the piers was most imperfect, cheapness appearing to be the ruling element in every detail, a cheapness too that must have been completely delusive, as any money saved in first cost would soon, in such a rickety structure, have been swallowed up in maintenance. At nearly all points an absence of consideration for small details is most apparent, indicating probably that these were intrusted to some subordinate, who failed to appreciate their importance.
It is very far from our object in this article to hold up any particular individuals to blame for this disaster, but we should like to point out on whom the responsibility should rest if such a thing should occur again.

It would be quite impracticable for the Board of Trade to exercise such supervision over the selection of the material and the execution and erection of a large work throughout its progress, as would render its certificate of any value ; we believe, therefore, that the undivided responsibility should rest on the engineer. Any dishonesty on the part of the contractor or his workmen,-and we are sorry to believe this still exists in some cases,-could be easily rendered hazardous by legal penalties.

Doubtless with the keen competition of the present day things must be "cut finer" than they used to be ; but while we would remove any arbitrary restrictions imposed by Government on the judgment of those who ought to be best able to appreciate the particular conditions of their own work, we should be very sorry to see the introduction of flimsy structures or reckless traffic arrangements without it being clearly understood on whom the responsibility rested in case of failure.

\section{CAMPS IN THE CARIBBEES}

Camps in the Caribbees. The Adventures of a Naturalist in the Lesser Antilles. By F. A. Ober. (Boston, U.S. : Lee and Shepherd; Edinburgh: Douglas, r880.)

THE author of this lively and very entertaining book 1 of travel undertook in 1876 the exploration of the Caribbees or Lesser Antilles, which islands extend over eight degrees of latitude between Porto Rico and Trinidad, connecting the Greater Antilles with the continent of South America. The islands had been hitherto little visited by naturalists, and the author made his expedition under the auspices of the Smithsonian Institution, with the especial object of collecting the birds of the group.

Around the borders of each island there is a cleared belt of fertile land, and on the coast often large villages and towns, whilst the interior is one vast forest covering wild hills and mountains. It was in the forests that the author's work lay. He took his camera into the mountains with him and photographed everything of interest which he met with, and the book is illustrated by numerous wood engravings of remarkably fine quality taken from the photographs and his sketches. About half the book, which is an octavo of 350 pages, describes adventures in the island of Dominica. Barbuda and Antigua were visited, but are not referred to at length. The account of the islands of St. Vincent, Grenada, Guadeloupe, and Martinique compose the remainder of the work, together with a catalogue of the birds of the group and descriptions of the sixteen new species of birds discovered.

Dominica was so named by Columbus, who happened to hit off the Lesser Antilles on his second voyage, because he sighted the island on a Sunday, November $3 \mathrm{rd}$, 1493. The island is most beautiful. The hills are broken and ragged, seamed, furrowed, and scarred, yet covered with a luxuriant vegetation of every shade of greenpurple of mango and cacao, golden of cane and limewhilst the ridges are crowned with palms, and behind Roseau, the capital, rises Lake Mountain, four thousand feet in height, five miles distant from the town, yet seeming to overshadow it.

$\mathrm{Mr}$. Ober started forthwith for the mountains, and 